\title{
Effect of Professional Ethics, Work Experience, and Emotional Intelligence on Auditor Opinion
}

\author{
Bambang Leo Handoko, Theresia Lesmana, Vincent Kosasih
}

\begin{abstract}
The auditor must prioritize professionalism in decision making, especially with regard to decisions related to audit results or opinions. Our study aims to understand impact by professional ethic, length of works, also emotional intelligent to ability in decision making. This study is provides primary data for hundred respondents who work at public accounting firm in South Jakarta. The data used in this research is primary data such as questionnaire. This research is conduct statistical methods to do hypothesis testing and causally research. Based on the partial results of hypothesis testing, professional ethic and emotional intelligent have a significant on auditor decision making effect however work experience has no significant effect on auditor decision making.
\end{abstract}

Keywords: Ethic, experience, intelligence, decision, auditor

\section{INTRODUCTION}

\section{A} udit has the function of auditing financial statements to provide an opinion on the truth of the presentation of the company's financial statements and also be one of the factors in decision making. This audit process is very important for a company to be audited because it will determine a value for the company that will have an impact on the investor's decision whether to invest in the company. Auditing financial statements issued by companies is a function owned by a public accountant. Publicly audited companies are companies that sell their shares to the public through large companies, small companies, non-profit organizations, and capital markets. Public accountants have an important role in society, especially in terms of increasing the credibility and quality of an entity's financial statements. So that the creditor and investor information users will be greatly influenced by public accountants before they make decisions or give their trust. [1]. As a form of community confidence, moral responsibility and professional responsibility are responsibilities that must be had in the public accounting profession. Therefore the auditor who audits a financial statement issued by a company must have moral responsibility as a basic competency that must be held, and

Revised Manuscript Received on December 30, 2019.

* Correspondence Author

Bambang Leo Handoko*, Accounting Department, Faculty of Economics and Communication, Bina Nusantara University, Jakarta, Indonesia, 11480. Email: bambang.handoko@binus.edu

Theresia Lesmana, Accounting Department, Faculty of Economics and Communication, Bina Nusantara University, Jakarta, Indonesia, 11480 Email: tlesmana@binus.edu

Vincent Kosasih, Accounting Department Faculty of Economics and Communication, Bina Nusantara University, Jakarta, Indonesia, 11480 Email: vincentkosasih99@gmail.com

(C) The Authors. Published by Blue Eyes Intelligence Engineering and Sciences Publication (BEIESP). This is an open access article under the CC BY-NC-ND license (http://creativecommons.org/licenses/by-nc-nd/4.0/) the auditor must have accountant responsibilities towards professional associations based on professional standards issued by the Indonesian Institute of Public Accountants (IAPI) which is a professional responsibility. The auditor has great confidence in the users of financial statements, so the auditor is required to continue to pay attention to audit quality [2]. Not only limited to the quality of audits produced, wider professional auditors in carrying out an independent appraisal function in a company viewed from the achievement of the performance of these auditors [3]. The reason was their responsibilities to maintain appearance is very important for the companies. The auditor is encouraged to understand the implementation of ethics which is the basis of the profession as an auditor and applies in carrying out his profession. Professional ethics is an organizational factor that will affect the performance of an auditor [4]. There are several important elements that must be possessed by an auditor, namely: (1) expertise and understanding of accounting standards or standards for financial statement preparation, (2) auditing / auditing standards, (3) professional ethics, (4) understanding the audited client business environment. Therefore, professional ethics is a basis which is essentially a self-regulation that determines the implementation of the profession as an auditor as expected by the public and investors in this modern era, the credibility of financial statements released to listed companies is one thing that should be considered by investors and creditors in investing in a company. In carrying out his profession, professional ethics are very important to be owned by the auditor because professional ethics is the basis for them behavior to do their job, along the upholding of professional ethics, the work carried out by the auditor will be able to do well. Professional ethics is the basis and also guidelines for auditors in carrying out their duties, if the auditor does not uphold ethics in the profession then everything he does will not comply with the guidelines and rules that apply in the profession. So this makes professional ethics very important to be owned by an auditor and has a significant effect on auditor decision making. This is in line with research conducted by [5] where ethical behavior positively affect the auditor decision making at public accounting firms in Bali.Every job that is done if it is equipped with work experience that is qualified will make all problems faced can be solved better. Experience is a natural teacher for all professions undertaken, in this case is the profession as an auditor, If the auditor has a lot of experience then when conducting an audit of the client company and encountered problems that occur that require the auditor to make a decision then the auditor will be able to more easy to make his decision because he already has enough experience. This makes work experience will affect auditor decision making. 


\section{THEORETICAL FRAMEWORK AND HYPOTHESIS}

\section{A. Auditor Opinion}

Decision making can be considered as an outcome or output from mental or cognitive processes that lead to the choice of an action pathway among the available alternatives [6]. Every decision making process always results in one final choice. The output can be an action (action) or an opinion on a choice.

Decision Making Results are considered effective if the alternative chosen is appropriate to the situation or problem that occurred. In the auditor's context, decision making is an important aspect of the auditor's responsibility. This is the process by which the auditor chooses the actions that are most logical and appropriate to the particular situation.

Decision making in an organization that creates an outcome is very important and should not be arbitrary, and certainly not just anyone who can determine a decision because the results resulting from decision making will have an impact on the organization. If an organization gives the authority to make decisions to just anyone, it does not deny that it could be that the resulting decisions will adversely affect the company.

Therefore, in carrying out audit activities that produce auditor decision making, several factors that support an auditor are required to make a decision to provide an audit opinion [6].

\section{B. Professional Ethics}

Professional ethics are the basis held firmly in a job that is done, with the existence of professional ethics. The profession can be accounted for and carried out professionally because it follows the applicable ethics that exist in the job. With the existence of professional ethics, the work we do will get the trust of both the parties concerned and the trust of the community.

Professional ethics is an organizational factor that will affect the performance of an auditor so that the main requirement that is obliged to uphold the applicable professional ethics rules [4]. Therefore professional ethics is a means of self-regulation that is crucial for the implementation of the profession as expected by the community. This is what makes the auditor must adhere to the ethics of his profession at work so as to determine good performance, which means that it will affect the opinion given. This is also in line with research conducted by [5] which states that professional ethics affect the accuracy of the opinion given by the auditor. By upholding professional ethics, it is expected that there will be no fraud among public accountants, so that auditors can provide opinions that are truly in accordance with the financial statements presented by their clients.

H1: professional ethics influence auditor opinion.

\section{Work Experience}

Experience is a good way of learning for internal auditors to make auditors rich in audit techniques. The higher the auditor's experience, the more capable and adept the auditor is in carrying out his own tasks and the activities he is auditing. Experience also forms the auditor able to face and resolve obstacles and problems in the performance of his duties, and is able to control emotional tendencies towards the party being examined. In addition to knowledge and expertise, the auditor's experience provides relevant contributions in increasing auditor competence [7].

Work experience is also a natural teacher for the auditor in determining a decision-making because with a lot of experience he has made it able to consider all factors well by using the experience they have, so that the resulting decision or audit opinion they provide can be more accurate [8].

If an auditor does not have so much experience in doing his work and when making a decision the auditor will consider his decision with the things he has at that time and does not have a previous foundation that he can use as a basis for making decisions.

H2: work experience influence auditor opinion

\section{Emotional Intelligence}

Emotional intelligence is a factor that must be possessed not only in the field of auditing but also in all the work it does. Because with everything that happens in the work environment or work pressure, sometimes we do a job that does not produce something positive or in accordance with what should be due to inadequate emotional intelligence that person has [9].

In organizational behavior, understanding attitude is important, because attitude will affect work. Attitudes provide an emotional basis for a person's interpersonal relationships and devotion. High emotional intelligence needed by the auditor because in the work environment, the auditor will deal with many people. In shaping the auditor's moral discipline, an important role of emotional intelligence is needed. Various problems and challenges that must be faced in the auditor's work world such as intense competition, task demands, and uncomfortable working atmosphere and relationship problems with others [10] and [11]. Good performance is produced by being able to control the emotions that are in themselves.

H3: emotional intelligence influences auditor opinion

\section{RESEARCH METHODOLOGY}

\section{A. Type and Source of Data}

In this study the authors use quantitative research, because we do hypothesis testing on this research. The data obtained will be in the form of numbers. Furthermore the numbers obtained will be further analyzed in data analysis, and the source of the data used is primary data. In this study primary data gathered via perceptions or opinion of people regarding related variables that have been distributed to auditors in the south Jakarta area.

\section{B. Data Collection Method}

In collecting samples, the authors use field research and the data used in this study are primary data. As for the way in determining the sample, the authors use a purposive sampling method. This is done by taking the subject not based on strata, random or region but based on the existence of certain objectives.

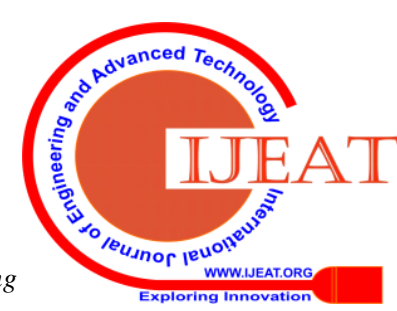


The activity of primary data collection which the writer does directly to the auditor who works at the Public Accountant Office in South Jakarta is the object of research. This is done so that the writer gets valid data from the auditors. The author himself will conduct field research by contacting several Public Accountant Offices in the South Jakarta area to be asked for their willingness to fill out a questionnaire that I will share.

\section{Population and Sample}

In conducting a study, the method of research is a scientific method used to obtain data as information for both the secondary and primary research actors with specific objectives and uses depending on what research is conducted. Retrieval of this data must use the correct and appropriate way so that the data obtained by researchers is a valid data so that it can be used as important and useful information in supporting the research process carried out by researchers. In conducting research, investigations and data collection must be carried out carefully, regularly and continuously to find out how the steps of the research should be carried out using research methods. So that the data obtained will be valid and reliable data can then be useful.

Population is a generalization area consisting of objects or subjects that have certain qualities and characteristics determined by researchers to be studied and then drawn conclusions. So the population is actually not only people but also objects or subjects along with their characteristics or characteristics. This research was conducted at several Public Accounting Firms located in the South Jakarta area.

The sample is part of the population selected using certain rules, which are used to collect information / data that describes the characteristics of the population. Although the sample is only part of the population, the facts obtained from the sample must be able to describe in the population.

As for the way in determining the sample, the authors use a purposive sampling method. This is done by taking the subject not based on strata, random or region but based on the existence of certain objectives. The number of samples to be used is $80-100$ samples.

\section{Analysis of Data}

Data analysis is done after getting the data that has been collected and process the data to get information on the research conducted.

The steps in analyzing data taken to examine and determine the effect of professional ethics, work experience, and emotional intelligence on auditor decision making is to collect primary data by distributing questionnaires to auditors working in public accounting firms (KAP) in the Jakarta area South. Then after the data is collected as a whole, I process the data obtained namely the influence of professional ethics, work experience, and emotional intelligence on auditor decision making using SPSS software with the aim of showing the relationship between the independent variable $(\mathrm{X})$ and the dependent variable (Y).

The research model used in this study is hypothesis testing and casualty research. Hypothesis testing is done to test an alleged relationship between variables. Whereas causality research is analyzing the relationship between the variables studied.

\section{E. Operation of Variables}

in order to measure the variables, we use indicators from previous research. the operation of each variables is stated in table- I

Table- I: Operation of Variables

\begin{tabular}{|l|l|}
\hline Variables & Dimension \\
\hline $\begin{array}{l}\text { Auditor opinion } \\
\text { (Y) [11] }\end{array}$ & $\begin{array}{l}\text { 1. Responsible for the findings } \\
\text { 2. Audit judgment in formulating opinion } \\
\text { 3. Audit judgment on materiality } \\
\text { 4. Judgment in audit risk }\end{array}$ \\
\hline $\begin{array}{l}\text { Professional } \\
\text { ethics (X1) [12] }\end{array}$ & $\begin{array}{l}\text { 1. Professional and moral judgment } \\
\text { 2. Cooperate with each other } \\
\text { 3. Maintaining public trust }\end{array}$ \\
\hline $\begin{array}{l}\text { Work experience } \\
\text { (X2) [5] }\end{array}$ & $\begin{array}{l}\text { 1. Professional quality of auditors } \\
\text { 2. Quality of auditor services } \\
\text { 3. Intellectual auditor } \\
\text { 4. Multidisciplinary knowledge of auditors }\end{array}$ \\
\hline $\begin{array}{l}\text { Emotional } \\
\text { Intelligence (X3) } \\
\text { [9] }\end{array}$ & $\begin{array}{l}\text { 1. Emotional skill } \\
\text { 2. Self motivation } \\
\text { 3. Self awareness } \\
\text { 4. Self defense }\end{array}$ \\
\hline
\end{tabular}

\section{RESEARCH RESULT}

\section{A. Identity of Respondent}

In the description of this data, the presentation of respondents' identities is attached, namely auditors in several Public Accountant Offices in the South Jakarta area. The following demographic data of respondents by sex, position of auditor, length of work, and type of Public Accountant Firm where they work.

Table- II: Identity of Respondent

\begin{tabular}{|l|r|l|r|}
\hline Gender: & & Audit Firm: & \\
\hline Male & 52 & Big four & 25 \\
\hline Female & 48 & Non big four & 75 \\
\hline Work experience: & Position: & \\
\hline $1-5$ years & 62 & Junior & 59 \\
\hline $6-10$ years & 21 & Senior & 29 \\
\hline $11-15$ years & 14 & Manager & 7 \\
\hline$>15$ years & 3 & Partner & 5 \\
\hline
\end{tabular}

Based on table-II, most respondents' identities are male, position as junior auditor, work experience 1 - 5 years and work in a non-big four public accounting firm.

\section{B. Reliability Test}

Reliability is the level of reliability of the questionnaire which if tested repeatedly to the same group would produce the same data.

According to [13], it is stated that a construct or variable is said to be reliable if it gives a Cronbach alpha value of more than 0.6 . If the reliability value $>0.60$ then the instrument is reliable where 0.60 is the standardization of the reliability value, but if the reliability value is less than 0.6 then it can be said that the variables in the questionnaire are not reliable. 
Table- III: Identity of Respondent

\begin{tabular}{|l|r|}
\hline Variables & Cronbach $\alpha$ \\
\hline $\begin{array}{l}\text { Auditor opinion } \\
(\mathrm{Y})\end{array}$ & 0.687 \\
\hline $\begin{array}{l}\text { Professional } \\
\text { ethics (X1) }\end{array}$ & 0.762 \\
\hline $\begin{array}{l}\text { Work experience } \\
(\mathrm{X} 2)\end{array}$ & 0.616 \\
\hline $\begin{array}{l}\text { Emotional } \\
\text { intelligence (X3) }\end{array}$ & 0.745 \\
\hline
\end{tabular}

Based on table-III, it is seen that the Cronbach's alpha value of all variables is greater than 0.6 so that it can be said that the variables of emotional intelligence, professional ethics, work experience, and auditor's decision making have reliable data so that this research instrument can be used to measure research objects the same one.

\section{Validity Test}

Each item is said to be valid if the correlation number obtained from the calculation is greater or equal to $r$ table [13]. To determine $\mathrm{r}$ arithmetic obtained from calculations with the corrected item-total correlation technical formula using SPSS.

Based on the results of the validity test, it shows that all indicators of the questions used to measure all the variables contained in this study are stated as valid items.

We can see the validity test in the formula: $r$ count $>r$ table. $\mathrm{R}$ table is taken from the product moment $\mathrm{r}$ table which uses numbers in df: $\mathrm{N}$ - number of items in the variable where the alphabet is $5 \%$.

Table- IV: Validity Test

\begin{tabular}{|l|r|l|r|}
\hline Variable & r count & Variable & r count \\
\hline ADM_1 & 0.576 & WE_1 & 0.529 \\
\hline ADM_2 & 0.716 & WE_2 & 0.575 \\
\hline ADM_3 & 0.561 & WE_3 & 0.572 \\
\hline ADM_4 & 0.612 & WE_4 & 0.571 \\
\hline ADM_5 & 0.692 & WE_5 & 0.535 \\
\hline PE_1 & 0.73 & WE_6 & 0.649 \\
\hline PE_2 & 0.751 & El_1 & 0.625 \\
\hline PE_3 & 0.693 & EI_2 & 0.649 \\
\hline PE_4 & 0.686 & EI_3 & 0.565 \\
\hline PE_5 & 0.734 & EI_4 & 0.618 \\
\hline PE_6 & 0.763 & EI_5 & 0.678 \\
\hline
\end{tabular}

\section{Coefficient Determination}

In order to find out the magnitude of the influence of the variables $\mathrm{x}$ and $\mathrm{y}$ can be used with determinant coefficients.

From the table below, it can be seen that the adjusted R2 produced is 0.513 or equal to $51.3 \%$. This shows that there is a very strong relationship between Professional Ethics, Emotional Intelligence and the auditor's work experience on decision making has a very strong relationship because the coefficient of determination is greater than 0.5 .
Table- V: Coefficient Determination

\begin{tabular}{|l|r|r|r|r|r|}
\hline Model & \multicolumn{1}{|c|}{$\mathrm{R}$} & R Square & \multicolumn{1}{c|}{$\begin{array}{c}\text { Adjusted R } \\
\text { Square }\end{array}$} & $\begin{array}{c}\text { Std. Error of the } \\
\text { Estimate }\end{array}$ & Durbin-Watson \\
\hline 1 & $.726^{\mathrm{a}}$ & .527 & .513 & 1.30637 & 1.725 \\
\hline
\end{tabular}

The magnitude of the correlation coefficient (R) is 0.726 while the value of the coefficient of determination ( $\mathrm{R}$ Square) is 0.513 with a standard error of 1.30637 . This means that $51.3 \%$ of the variation in Decision Making can be explained by variations in the Professional Ethics, Work Experience, and Emotional Intelligence variables of the Auditor, that is, the terms X1, X2, and X3 affect the Decision Making (Y) of the remaining auditor $(100 \%-51.3 \%=48.7 \%)$ explained by other variables not included in this study.

\section{E. Multiple Regression Simultaneous Test}

F test in multiple regressions is used to find out whether the independent variable regression model partially has a significant effect on the dependent variable. In order to find out whether or not the influences of each independent variable impact the dependent variable, it can be seen by comparing the probability value (p-value) of each variable with a significance level used of 0.05 . If the significance level $<0.05$, then the hypothesis Ho is rejected and Ha is accepted, and it can be said that the independent variables in this regression model have a significant effect on the dependent variable. And also F count must be greater than $\mathrm{F}$ table ( $\mathrm{F}$ Calculate $>$ F Table). F Table can be seen in the distribution table $\mathrm{F}$ whose $\mathrm{F}$ is 100 and the $\mathrm{df}$ is:

$=$ free variable - bound variable

$=3-1$

$=2$; produce an $\mathrm{F}$ table of 3.08 .

The following are the results of the $\mathrm{F}$ Test conducted using SPSS:

Table- VI: F Test

ANOVA

\begin{tabular}{|rl|r|r|r|r|r|}
\hline \multicolumn{2}{|l|}{ Model } & Sum of Squares & \multicolumn{1}{c|}{ df } & Mean Square & \multicolumn{1}{c|}{ F } & \multicolumn{1}{l|}{ Sig. } \\
\hline $1 \quad$ Regression & 182.757 & 3 & 60.919 & 35.696 & $.000^{\circ}$ \\
& Residual & 163.833 & 96 & 1.707 & & \\
\hline \multicolumn{2}{|l|}{ Total } & 346.590 & 99 & & & \\
\hline
\end{tabular}

From the results above it can be seen that the significant value is 0.000 , which means less than $0.05(0.000<0.05)$ so it means that the professional ethics variable (X1), work experience (X2), and emotional intelligence (X3) together have a significant effect together. on auditor decision making.

And if we look at the F count of 35,696 and greater than the F table of 3.08 so it means that professional ethics, work experience, and emotional intelligence together have a significant effect on auditor decision making.

\section{F. Partial Hypothesis Test}

$\mathrm{T}$ test in multiple regression is used to determine whether the independent variable regression model partially has a significant effect on the dependent variable.

In order to find out, is it true or not the influence of each independent variable impact dependent variables. 

(p-value) of each variable with a significance level used of 0.05 . If the significance level $<0.05$, then the hypothesis Ho is rejected and $\mathrm{Ha}$ is accepted, and it can be said that the independent variables in this regression model have a significant effect on the dependent variable. And also T count must be greater than $\mathrm{T}$ table ( $\mathrm{T}$ Count $>\mathrm{T}$ Table). $\mathrm{T}$ Table can be seen in the distribution table $\mathrm{T}$ whose $\mathrm{F}$ is 100 and the alphabet is 0.05 which will get a figure of 1.99 .

The following are the results of t-tests conducted using SPSS:

\begin{tabular}{|c|c|c|c|c|c|c|}
\hline \multirow{2}{*}{\multicolumn{2}{|c|}{ Model }} & \multicolumn{2}{|c|}{ Unstandardized Coefficients } & \multirow{2}{*}{$\begin{array}{c}\text { Standardized } \\
\text { Coefficients }\end{array}$} & \multirow[b]{2}{*}{$\mathrm{t}$} & \multirow[b]{2}{*}{ Sig. } \\
\hline & & B & Std. Error & & & \\
\hline & (Constant) & 3.740 & 2.124 & & 1.761 & .081 \\
\hline & $\mathrm{x} 1$ & 390 & .067 & .525 & 5.809 & .000 \\
\hline & $\mathrm{x} 2$ & .100 & .055 & .130 & 1.807 & .074 \\
\hline & $\mathrm{x} 3$ & .253 & .093 & .242 & 2.720 & .008 \\
\hline
\end{tabular}

Professional ethics (X1)

$\mathrm{X} 1$ has a significant value of 0,000 and is smaller than 0.05 $(0,000<0.05)$ which means that X1 has a significant effect on auditor decision making. X1 has a t count of 5.809 which means it is greater than table that is 1.99 , which means that $\mathrm{X} 1$ has a significant effect on auditor decision making. Work experience (X2) (0.074>0.05) so that it means that X2 has no significant effect on auditor decision making. X2 has a t count of 1,807 which means it is smaller than t table that is 1.99 , which means that X2 has no significant effect on auditor decision making.

Emotional Intelligence (X3)

X3 has a significant value of 0.008 and smaller than 0.05 $(0.008<0.05)$ so it means that X3 has a significant effect on auditor decision making. X3 has a t count of 2,720 which means it is greater than table that is 1.99 , which means that X3 has a significant effect on auditor decision making.

\section{CONCLUSION AND SUGGESTION}

\section{A. Conclusion}

This study aims to determine the effect of professional ethics, work experience, and emotional intelligence of auditors on auditor decision-making on auditors working in public accounting firms in the South Jakarta area. Based on the results of research and data processing on 100 questionnaires distributed to public accounting firms in the south Jakarta area that have been done and discussed in the previous chapter, the conclusions of this study are as follows:

According to the results of the SPSS calculations on the results of the questionnaire distribution that has been obtained, it can be concluded that professional ethics have a significant effect on auditor decision making. If the auditors apply professional ethics in carrying out their profession well, they will make decisions taken in accordance with client needs. This is because professional ethics are the basis for auditors in carrying out various activities related to their profession as auditors, if their professional ethics are good then the decision making will be in accordance with what they should take but if their professional ethics are not good then their decision making will not as it should be. So this
The method is by comparing the probability value

$\mathrm{X} 2$ has a significant value of 0.074 and greater than 0.05

causes professional ethics to be important in doing every job, both as an auditor and other professions. With the upholding of professional ethics, the work done by workers can be better and more true in accordance with the provisions that apply in every profession that is undertaken, if seen from this research, what is meant is that auditors can work and make good decisions on audits performed in accordance with the rules that apply in the audit profession in Indonesia. This result is in line with [4], [5] and [12].

According to the results of SPSS calculations on the results of the questionnaire distribution data that have been obtained, it can be concluded that the auditor's work experience has no significant effect on the auditor's decision making. This means that the longer an auditor works, this does not necessarily make it easy and correct according to the needs of the client in making a decision. Our result support [3] and [14], but opposite with [15] and [16].

According to the results of SPSS calculations on the results of the questionnaire distribution data that has been obtained, it can be concluded that emotional intelligence has a significant effect on auditor decision making. In this case it means that if the auditors have good emotional intelligence, the decisions they make will be in accordance with client needs. This is because emotional intelligence is the basic thing that influences someone to make an appropriate decision or not. This result support [9], [10] and [11]

\section{B. Suggestion}

Based on the conclusions that have been submitted above, it can be given a number of suggestions where this research in the future is expected to be able to present higher quality research results with the existence of some input regarding several things, including:

Future studies need to add direct interview methods to each respondent in an effort to collect data, so as to avoid the possibility of respondents not being objective in filling out the questionnaire. In order to expand the research population so that it can represent all auditors working at the existing Public Accounting Firm. In further research, it can be added or use other variables besides those in this study to better know what factors can influence auditor decision making.

Implication of our research for the Public Accounting Firm, in order to create training that can strengthen professional ethics so that auditors who conduct audits of client companies can uphold the ethics of their profession. Then make training that can increase the emotional intelligence of auditors so that auditors who conduct audits of client companies can maintain emotional intelligence.

\section{REFERENCES}

1. Y. K. Bangun and M. Asri, "Auditor Ethical Decision Making," Sci. Res. J., no. VI, 2017.

2. B. L. Handoko, R. Widuri, T. Andrian, and J. I. Darmasaputra, "Do work experience, good governance, and independence influence the audit quality?," Int. J. Innov. Technol. Explor. Eng., 2019.

3. E. E. Griffith, J. S. Hammersley, K. Kadous, and D. Young, "Auditor mindsets and audits of complex estimates," J. Account. Res., 2015.

4. T. C. Omer, N. Y. Sharp, and D. Wang, "The Impact of Religion on the Going Concern Reporting Decisions of Local Audit Offices," J. Bus. Ethics, 2016.

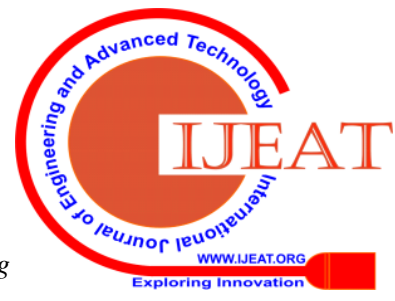


5. A. Zarefar, Andreas, and A. Zarefar, "The Influence of Ethics, Experience and Competency toward the Quality of Auditing with Professional Auditor Scepticism as a Moderating Variable," Procedia Soc. Behav. Sci., 2016.

6. S. M. Glover, M. H. Taylor, and C. Western, "Mind the Gap: Why Do Experts Have Differences of Opinion Regarding the Sufficiency of Audit Evidence Supporting Complex Fair Value Measurements?," Contemp. Account. Res., 2019.

7. H. Guénin-Paracini, B. Malsch, and A. M. Paillé, "Fear and risk in the audit process," Accounting, Organ. Soc., 2014.

8. B. L. Handoko, H. H. Muljo, and A. S. L. Lindawati, "The effect of company size, liquidity, profitability, solvability, and audit firm size on audit delay,” Int. J. Recent Technol. Eng., 2019.

9. G. E. Jones, "University of Wollongong Theses Collection The link between emotional intelligence and graduate qualities: implications for accounting education," 2008.

10. S. Bhattacharjee and K. K. Moreno, "The role of auditors' emotions and moods on audit judgment: A research summary with suggested practice implications," Curr. Issues Audit., vol. 7, no. 2, pp. 1-8, 2013.

11. M. Abuaddous, H. Bataineh, and E. Alabood, "Burnout and auditor's Judgment Decision Making: An experimental investigation into control risk assessment," Acad. Account. Financ. Stud. J., vol. 22, no. 4, pp. 1-16, 2018.

12. J. Peterson, “Auditor Independence,” Bus. Prof. Ethics J., 2018.

13. U. Sekaran and R. Bougie, Research Method For Business. 2014.

14. O. Furiady and R. Kurnia, "The Effect of Work Experiences, Competency, Motivation, Accountability and Objectivity towards Audit Quality," Procedia - Soc. Behav. Sci., vol. 211, pp. 328-335, 2015.

15. S. Corbella, C. Florio, G. Gotti, and S. A. Mastrolia, "Audit firm rotation, audit fees and audit quality: The experience of Italian public companies," J. Int. Accounting, Audit. Tax., 2015.

16. G. Matonti, J. Tucker, and A. Tommasetti, "Auditor choice in Italian non-listed firms," Manag. Audit. J., vol. 31, no. 4-5, pp. 458-491, 2016.

\section{AUTHORS PROFILE}

Bambang Leo Handoko, Assistant Professor, he holds double master degrees, Master Degree of Accounting from Trisakti University and Master of Management form Kalbis Institute, both in Jakarta, Indonesia. His research field is in the scope of financial and fraud auditing. He was expert in forensic accounting and fraud examination. He has become reviewer and keynote speech in some international conference. He is member of Indonesian Accounting Council. Currently work as faculty member and subject content coordinator in Bina Nusantara University. He earns best sit in peer review coordinator from Bina Nusantara University in 2016, and then won best teaching award from Bina Nusantara University in 2018.

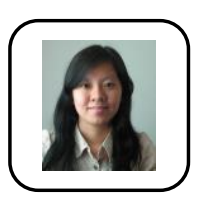

Theresia Lesmana, Lecturer. She was born in Jakarta on December 16, 1988. She is a graduate in accounting at Bina Nusantara University, Jakarta. Then he continued his S2 studies at the University of Indonesia in 2013 2015 with a major in Accounting.

She has work experience as Coordinator of Accounting and Finance Laboratory and Head of Accounting and Finance Laboratory. He also served as an activist and administrator in the KMB Dhammavaddhana organization from 2007 to 2010. From 2015 until now, she has served as Deputy Head of Department - Accounting (Alam Sutera Campus). Her research interest is in the field of Accounting and Finance

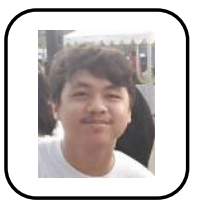

Vincent Kosasih, he holds bachelor's degree in accounting from Bina Nusantara University, Jakarta Indonesia. He graduated with excellent achievement. His research interest is in the field of financial auditing, professional ethics and corporate governance. He has experience in auditing work from internship activities in public accounting firm. He also actively engaged in many community development activities. The activities example is like teaching the pre-school students, teaching societies. Joseph has passion and care about kids. Currently he works as an entrepreneur, opening start up of his own business. The subject and soft skill which he learns from university is very necessary in conducting business 